\title{
半導体材料・デバイスの最新の進展 \\ Recent Advancement of Semiconductor Materials and Devices
}

\section{講座の開始にあたって}

「半導体デバイス」という語に用いられている「デバイス (device)」とは，「工夫」という意味の語である，材料， 構造, 用途に対して，「土夫」を凝らされた集大成が「半導体デバイス」である，材料に焦点を当てると，その選定， 作製技術，特性の制御などに，幅広い「工夫」がなされており，これが新しいデバイスの実現につながり，社会に波及 効果をもたらすわけである。良い例が，2014 年のノーベル物理学賞の対象となった青色 LED で, GaN と InGaN という 材料を選択したこと，低温バッフア層の導入で高品質の結晶が得られたこと, $\mathrm{p}$ 型・ $\mathrm{n}$ 型の電気特性制御を達成できた こと，等が結集した成果であったと言えよう。この流れは，多様なデバイスを目指寸多くの研究者の着想に支えられた 進展を続けており，現在では想像できないデバイスが未来の社会に貢献すると期待される.

この半導体・エレクトロニクスの分野は, 本会にあっては会員数の少ない分野である. 逆に多くの会員の方にとって は，この分野は所縁の浅いところである。一方で，ノーベル賞や半導体不況といった，良くも悪くも話題の多い分野で ある。このことから，多くの会員の方に半導体材料とデバイスの研究開発の現状を知っていただきたいことを願い，以 下の 4 回からなる連載講座を企画した。

1. 酸化物半導体の物性とデバイス

2. 分子線エピタキシャル成長とデバイス応用

3. 太陽電池の変換効率限界を引き上げる半導体材料設計

4. 電着法による酸化亜鉿の薄膜および厚膜の成長

金子健太郎（京都大学）

富永依里子（広島大学）

朝日重雄, 喜多隆 (神戸大学)

宇野和行（和歌山大学）

この分野の基礎的な部分は多くの書籍等で述べられている。そこで，本講座では，日頃から自らの手で日夜実験に取り 組んでおられる研究者にその生の声としての執筆をお願いし，ご自身の研究を話題としてわかりやすくその背景, 意義, 波及効果をご紹介いただくことにより，会員の方には，この分野の研究開発の基本的な考え方や今後の展開についてふ れていただくことを意図した。専門が遠い方には最近の話題として，近い方にはご自身のご研究との接点を見つけてい ただくものとして，本講座がお役に立つことができればと念じている.

(半導体・エレクトロニクス部門委員会 藤田 静雄 (京都大学 大学院工学研究科))

\section{1. 酸化物半導体の物性とデバイス応用}

金子 健太郎*

\section{I: Physical Properties of Oxide Semiconductors and Their Applications for Electrical Devices}

by

\section{Kentaro KANEKO*}

This paper reviews physical properties and device applications of oxides, especially corundum-structured oxides. Oxides had been considered as unwelcome interruptions in puddling cupper or iron at first. However, after the invention of barium titanate, it begun to attract attentions for their varied functions. As well as an evolution of fabrication techniques and equipment, it could be realized to fabricate high-quality oxide thin films free from impurities. Various physical functions in oxides have been unraveled. Furthermore, in these days, meta-stable oxides can be grown under atmosphere at low temperature by mist CVD method. Corundum-structured oxides has been gathering much attentions for these abilities for electrical device applications.

Key words:

Oxide, Meta-stable, Semiconductor, Wide bandgap, Power devices, Mist CVD, Schottky barrier diodes, Corundum-structured oxide thin film

1 緒言

古来より酸化物は，鉱物という形で身近に存在してい た。しかし古来の人類にとって酸化物は，有用な金属の
表面に形成される「邪魔者」でしかなく，それを除去す るための技術が発展した ${ }^{1)}$. 例えば, 最も身近な鉄は酸化 鉄 $\left(\mathrm{FeO}, \mathrm{Fe}_{3} \mathrm{O}_{4}, \mathrm{Fe}_{2} \mathrm{O}_{3}\right)$ の形で地上に露出するため, 強

$\dagger$ 原稿受理 平成28年 8月 24日 Received Aug. 24, 2016 (2017 The Society of Materials Science, Japan

* 正 会 員 京都大学 工学研究科 光・電子理工学教育研究センター ₹615-8520 京都市西京区京都大学桂

* Photonics and Electronics Science and Engineering Center, Kyoto University, Nishikyo-ku, Kyoto 615-8520. 
固に結合した酸素を取り除く必要があった。しかしなが ら，融点 $\left(1539{ }^{\circ} \mathrm{C}\right)$ が高い鉄の精錬は難しく，一方で銅は 融点が比較的低く $\left(1083^{\circ} \mathrm{C}\right)$, 木材などの燃料でも容易に 溶か寸事が出来たため，鉄より先に青銅器の時代が先行 した。このように当初の人類は酸化物を「除く」事で高 純度の金属を精錬する事に技術の意義を見出し，ガラス や陶器等を除き, 酸化物自体を活用する事は考えなかっ た ${ }^{2)}$ ，それは金属と異なり延性，展性がそしくねばりが無 いため, 武器や工具, 農具をはじめとする身辺で使用す る耐久品に適さなかった事が大きな原因である。その認 識は現代社会でも同様であり，橋脚や鉄塔の防錆剤とし て塗布される赤錆 (酸化鉄 $\alpha-\mathrm{Fe}_{2} \mathrm{O}_{3}$ ) や, 絶縁碍子, 人工 歯等の比較的小さいセラミック構造体, 一部の電子デバ イスの構成体以外には応用先が少ない.

しかしながら，酸化物にはその多様な物性に由来する 機能が備わっており，それは他の化合物では置き換えで きないものも多い. その端緒として 1942 年に圧電セラミ ック材料としてチタン酸バリウム $\left(\mathrm{BaTiO}_{3}\right)$ が見出され, 続 いて 1955 年にはさらに圧電性に優れた PZT $\left(\mathrm{Pb}(\mathrm{TiZr}) \mathrm{O}_{3}\right)$ セラミックスが発見された ${ }^{3)}$.これらは圧電振動子として 応用され, 超音波加工機, 洗浄機や医療機器に用いられ ている。しかしこれらはあくまで焼結体であった。純度 の高い酸化物単結晶インゴットおよび薄膜を作製する事 は当時困難であり, 結晶成長技術の成熟を待たなければ いけなかった。

酸化物の機能が一気に注目を集めたのは 1986 年であつ た. Bednorz と Müllerによる La-Ba-Cu-O 系 $\mathrm{K}_{2} \mathrm{NiF}_{4}$ 型構造 をもつセラミック焼結体の電気抵抗測定結果が発表され 4), それに興味をもった田中らによってバルク体での追実 験がなされ 5), 1987 年に Chu によって初めて液体窒素温 度を超える転移温度 $(93 \mathrm{~K})$ をもつ Y-Ba-Cu-O 系超伝導 体が報告された ${ }^{6)}$. いずれの物質も銅 $(\mathrm{Cu})$ 系の酸化物であ る事から, 酸化物の物性研究が本格的にスタートするき っかけとなった．その後の研究によって銅酸化物系高温 超伝導体の転移温度は $\mathrm{HgBa}_{2} \mathrm{Ca}_{m-1} \mathrm{Cu}_{m} \mathrm{O}_{2 m+2+\delta}(m=1,2,3)$ の $164 \mathrm{~K}$ が報告されている7). さらに 2008 年に細野らに よって鉄系超伝導体 $\mathrm{LaFeAsO}$ が発明され ${ }^{8)}$, 新たな材料 群として注目されている。このように突出した機能をも った酸化物の登場により, 未発見の機能性酸化物の「宝 探し」や, 既知の酸化物の中での新たな物性探索研究が 活発化した。 また, その機能探索研究の中で従来の焼結 体，バルク作製から，スループットの高い，高品質薄膜 作製による機能探索が行われた.

\section{2 典型金属酸化物の物性とデバイス応用}

\section{$2 \cdot 1$ 典型金属酸化物の物性}

酸化物(無水酸化物)をその化学的性質から分類すると, 水に溶解した時にプロトン $\left(\mathrm{H}^{+}\right)$を放出する酸性酸化物 (acidic oxide), 逆に周りの水分子からプロトンを受け取 る塩基性酸化物 (basic oxide), そして両方の性質をもつ両
性酸化物 (amphoteric oxide) の 3 つに分けられる. 酸性酸 化物は主に非金属元素との酸化物を, 塩基性酸化物は主 に金属元素との酸化物の事を指し, 両性酸化物には Be,

$\mathrm{Al}, \mathrm{Ga}, \mathrm{In}, \mathrm{Ge}, \mathrm{Sn}, \mathrm{Pb}$, そして酸化数が低い状態での $\mathrm{As}, \mathrm{Sb}, \mathrm{Bi}$ の酸化物が挙げられる ${ }^{9)}$.つまり $\mathrm{SiO}_{2}$ を除く 金属酸化物は塩基性酸化物または両性酸化物のどちらか である(Table 1).

本論文では，この金属酸化物を典型元素に属する金属 との酸化物(典型金属酸化物) と, 遷移元素に属する金属亡 の酸化物(遷移金属酸化物)に分類寸る. 典型金属酸化物は, 主に $\mathrm{s}$ 電子軌道, $\mathrm{p}$ 電子軌道から構成される等方的な電子 軌道によって伝導帯が形成されており, 比較的電子移動 度も高く, 電子デバイスへの応用が期待される材料群で ある. 一方, 遷移金属酸化物は主に $\mathrm{d}$ 電子軌道, $\mathrm{f}$ 電子軌 道が伝導体および価電子帯を形成し, 電子の移動が非常 に局在化された材料群である。 そのため移動度も極端に 小さく, 電子デバイスへの応用は難しい. しかしながら, $\mathrm{d}$ 電子, $\mathrm{f}$ 電子のスピンに由来する様々な物性を示し, 機 能性材料としての応用が期待されている ${ }^{10)}$.

このように酸化物はその構成電子の多様さから多くの 物性を示す. 酸化アルミニウム $\left(\alpha-\mathrm{Al}_{2} \mathrm{O}_{3}\right)$ や酸化珪素 $\left(\mathrm{SiO}_{2}\right)$ に代表される絶縁体, 酸化亜鉛 $(\mathrm{ZnO})$, 酸化インジウム $\left(\mathrm{In}_{2} \mathrm{O}_{3}\right)$, 酸化錫 $\left(\mathrm{SnO}_{x}\right)$ ような半導体, 四酸化三鉄 $\left(\mathrm{Fe}_{3} \mathrm{O}_{4}\right)$, 酸化ユウロピウム $(\mathrm{EuO})$ 等の磁性体, そしてチタン酸バリ ウムや PZT 等の圧電体, 二オブ酸リチウム $\left(\mathrm{LiNbO}_{3}\right)$ など の強誘電体 ${ }^{3)}$, そして前述のような超伝導体である.

\section{$2 \cdot 2$ 典型金属酸化物の半導体デバイス応用}

酸化物の半導体としての性質を $\mathrm{Si}$ や $\mathrm{GaAs}$ と比較する と, 一般に移動度が 2 けた以上小さい. それ以外に結晶 中の酸素空孔量の制御が困難である事, ぜい性を示す事, そして結晶多形が多く存在し，熱や圧力による結晶型の 変化に注意する必要がある等，半導体材料への応用にお いても不利な点が多い.これらのネガティブな点が現在 まで酸化物の単結晶電子材料が存在しない大きな理由で ある.また, 酸化物の結晶多形が存在する理由として, 共有結合でつながっている Si は電荷担体の軌道半径がお およそ $30 \AA$ であるが, 共有結合性とイオン結合性によっ てつながっている酸化物は酸素の電気陰性度が大きいた め電子が $\mathrm{Si}$ 等に比べて局在化しており, 基本的な軌道半 径は $1 \AA$ 程度である ${ }^{10)}$. 軌道半径が小さいという事は結 晶の結合を形成するために高密度に原子同士が重なり合 う必要があり, これが密度や温度に応じて容易に結晶構

\begin{tabular}{|c|c|c|c|}
\hline Formatio & Basic Oxide & Amphoteric Oxide & Acidic Oxide \\
\hline Ex. & Metal & Metal & Nonmetal \\
\hline
\end{tabular}

Table 1 A classification of oxides as a function of formatio. 
造が変形する理由である.

しかしながら，近年の薄膜成長技術の発展により，製 膜時の酸素分圧のコントロールが可能となり，薄膜中の 酸素欠損量のコントロールもある程度までは制御出来る ようになった。 また，パルスレーザー堆積法(Pulsed laser deposition:PLD)や分子線エピタキシー法(Molecular beam epitaxiy: MBE), スパッタリング法等の非平衡状態を実現 できる高真空製膜装置の登場により，融液法等では作製 が困難であった，異なる融点をもつ金属の合金や混晶の 作製が可能となった，さらに，PLD，MBE 手法では合金 や混晶の精密な組成制御が実現し, 酸化物においても精 密な金属組成制御を行う事が可能になった。

これらの薄膜作製技術の進歩により，酸化物の半導体 応用研究において大きな成果を挙げたものが $\mathrm{ZnO}$ である 2007 年に塚崎, 川崎らによって酸化物で初めて整数量子 ホール効果 ${ }^{12)}$, そして分数量子ホール効果 ${ }^{13)}$ の観察が報 告された. それまでは GaAs 等の極めて清浄な薄膜界面の みで観察されていた現象が酸化物で確認された事から, 酸化物結晶薄膜成長技術の発展を示寸結果となった。さ らに，同グループによる $\mathrm{p}$ 型 ZnO の作製による青色 LED の実証 ${ }^{14)}$ は, 酸化物の膜中の不純物濃度を精密に制御可 能である事を示している.

さらに近年では，準安定相の酸化物を大気圧下で比較 的低温の結晶成長条件にて作製出来る手法が開発された それはミスト CVD 法(超音波噴霧ミスト気相成長法) と呼 ばれるものであり 15), 16)，真空を必要としないため PLD やMBE等の従来の真空製膜手法に比べ低いエネルギーで の製膜が可能である(Fig.1). そのため比較的低温，大気圧 下での結晶成長が実現出来，基板表面での飛来原子のマ イグレーション速度が比較的小さくなり，下地基板の結 晶からの応力による拘束が結晶成長時に大きな影響を与 える事となる ${ }^{17)}$.この特徵を応用する事で, 準安定相金属 酸化物であっても結晶構造が近い基板を選択する事で成 長出来る事が報告されている ${ }^{18) ~ 19) 20) 。 ~ ま た ， ミ ス ト ~ C V D ~}$ 法を用いる事で，多くの 3d-ブロック元素，III 族，IV 族 酸化物が作製可能である(Fig. 2$)^{2)}$ 。一方で，他の典型金属 酸化物も半導体, そしてその周辺材料としての応用があ る. I 族の酸化リチウム $\left(\mathrm{LiO}_{x}\right)$ は次世代の全固体電池用の 導電性材料として注目されており ${ }^{21)}$ ， その正極材料に用 いるマンガン酸リチウム $\left(\mathrm{LiMn}_{2} \mathrm{O}_{4}\right)$ は, 2011 年にミスト CVD 法による最初の薄膜作製が報告され ${ }^{22)}$ ，後に同法で 作製した電極の電気特性が報告された ${ }^{23)}$. II 族の酸化べ リリウム $(\mathrm{BeO})$, 酸化マグネシウム $(\mathrm{MgO})^{23}$ は半導体用の 放熱材料, $\mathrm{ZnO}$ との混晶化による深紫外固体光源への研 究, III 族の $\mathrm{Al}_{2} \mathrm{O}_{3}{ }^{25)}, \mathrm{Ga}_{2} \mathrm{O}_{3}{ }^{26)}$ 28), $\mathrm{In}_{2} \mathrm{O}_{3}{ }^{29)}$ はそれぞれ, ゲート絶縁膜材料や太陽電池用のパッシベーション膜, 深紫外検知器や次世代パワーデバイス材料, 新しい MOSFET 用チャネルとして, IV 族の $\mathrm{SiO}_{2}, \mathrm{SnO}_{x}(x=1$, 2) は, Si デバイスの良好な絶縁体材料, 一酸化炭素(CO) をはじめとするガスセンサー ${ }^{30}$ への応用研究がなされて
おり, 酸化物を半導体として用いる研究分野が今後増加 する事が予想される.

これらの典型金属酸化物の中で興味深いのは両性酸化 物である $\mathrm{Al}_{2} \mathrm{O}_{3}, \mathrm{Ga}_{2} \mathrm{O}_{3}, \mathrm{In}_{2} \mathrm{O}_{3}$ による混晶系である.これ らの最安定相の結晶構造は, それぞれコランダム構造, $\beta$-gallia 構造, bixbyite 構造であり, 3 つとも異なる結晶構 造をもつ(Fig.3). しかしながらその準安定相はすべてコラ ンダム構造である．前述のように，ミストCVD 法を用い ることでこれらの準安定相酸化物が作製可能であり 18),31),32)， $\mathrm{SiC}$ や $\mathrm{GaN}$ といった従来のワイドバンドギャッ プ半導体を超える，3.7-9.0 eV のバンドギャップ制御が可 能な新しい混晶系として次世代パワーデバイスや深紫外 固体素子への応用が期待出来る(Fig.4 $)^{33)}$. 多くの典型金属 酸化物の中で, 準安定相も含めて半導体応用可能なバン ドギャップをもち, さらに同じ結晶構造による高品質の 混晶系を作製した報告があるのはこの混晶系のみである. 本論文ではこれまであまり詳述されることがなかった， 典型金属コランダム構造酸化物の物性について次章で述 べる.

\section{3 コランダム構造酸化物の物性とデバイス応用}

\section{$3 \cdot 1$ コランダム構造酸化物の特徵}

コランダム(Corundum)は日本名で鋼玉と呼ばれ，アル ミニウムの酸化物の鉱物名であり, $\alpha-\mathrm{Al}_{2} \mathrm{O}_{3}$ の単結晶とし て天然に産出寸る.これにCrが少量混入しているものが 赤色の紅玉(Ruby)であり, FeやTiを含有するものが青玉 (Sapphire)である.これまでにコランダム構造をとる結晶 は $\alpha-\mathrm{Al}_{2} \mathrm{O}_{3}$ 以外にも酸化ガリウム $\left(\alpha-\mathrm{Ga}_{2} \mathrm{O}_{3}\right)$, 酸化インジ ウ $\left(\alpha-\mathrm{In}_{2} \mathrm{O}_{3}\right)$, 酸化鉄 $\left(\alpha-\mathrm{Fe}_{2} \mathrm{O}_{3}\right)$, 酸化クロ $ム\left(\alpha-\mathrm{Cr}_{2} \mathrm{O}_{3}\right)$, 酸化バナジウム $\left(\alpha-\mathrm{V}_{2} \mathrm{O}_{3}\right)$, 酸化チタン $\left(\alpha-\mathrm{Ti}_{2} \mathrm{O}_{3}\right)$, 酸化口 ジウム $\left(\alpha-\mathrm{Rh}_{2} \mathrm{O}_{3}\right)$ の計8種が報告されている ${ }^{34), 35)}$.この中 で熱エネルギー的に最安定相であるのは $\alpha-\mathrm{Al}_{2} \mathrm{O}_{3}$,

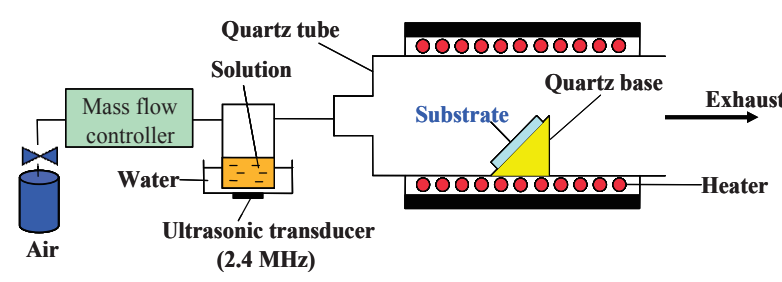

Fig. 1 A schematic image of hot-wall type mist CVD device.

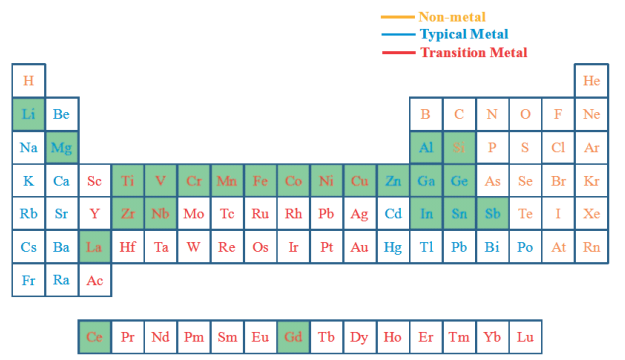

Fig. 2 Metal oxides filled with diagonal lines can grow by mist CVD method in a periodic table ${ }^{2)}$. 


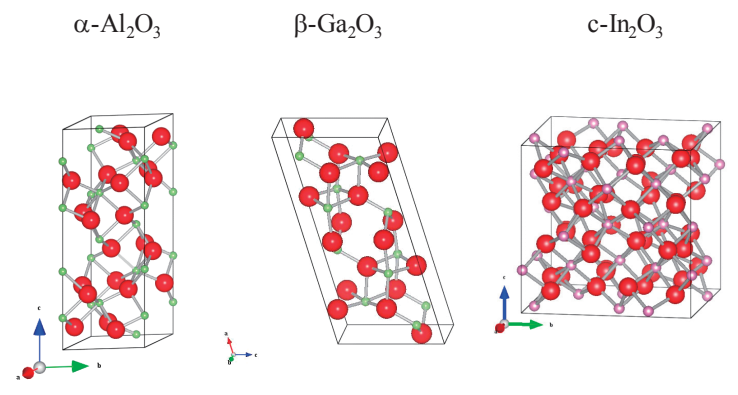

Fig. 3 Crystal structures of thermal-stabilized phase of $\mathrm{Al}_{2} \mathrm{O}_{3}$, $\mathrm{Ga}_{2} \mathrm{O}_{3}$ and $\mathrm{In}_{2} \mathrm{O}_{3}$.

$\alpha-\mathrm{Fe}_{2} \mathrm{O}_{3}, \quad \alpha-\mathrm{Cr}_{2} \mathrm{O}_{3}, \alpha-\mathrm{Rh}_{2} \mathrm{O}_{3}$ のつづあり，他は不安定ま たは準安定相である。

コランダム構造は $\mathrm{A}_{2} \mathrm{~B}_{3}$ 型イオン結晶構造であり, 酸素 原子の六方最密充填構造を基礎として酸素原子の間に ある八面体配位の孔のうち $2 / 3 の$ 箇所に金属原子が充填 しており，1/3は空孔となっている。また167番の空間群 である $R \overline{3} c$ に属し, 結晶点群は三方晶系の $\overline{3} m\left(D_{3 d}\right)$ に属し,

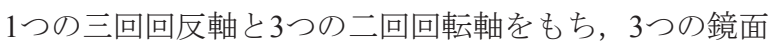
がある比較的結晶内の対称性が高い化合物である。その ため結晶内部には圧電性, 自発分極, 旋光性はなく, $\mathrm{ZnO}$ やGaNのように+c面, -c面による結晶配列の違いがない. また結晶自体に䢃開はなく，\{0001\}と\{1011\}面において 裂開する。

\section{$3 \cdot 2$ コランダム構造典型金属酸化物の物性}

コランダム構造典型金属酸化物のうち $\alpha-\mathrm{Al}_{2} \mathrm{O}_{3}$ のみが 熱的最安定相として結晶成長が容易である. また, 主に GaN-LEDの基板や光学部品として用いられ, 半導体用基 板として広く用いられている. しかしながら, その光学 バンドギャップ值は様々に報告されており， 8.55 $5^{36)}$, $8.75 \mathrm{eV}^{37)}$ など報告されている。これは $\alpha-\mathrm{Al}_{2} \mathrm{O}_{3}$ 結晶内の欠 陥やFeや $\mathrm{Cr}, \mathrm{Ni}$ の不純物によって7.0 eV(Cr $)^{38)}, 7.2 \mathrm{eV}(\mathrm{Cr}$, $\mathrm{Ni}, \mathrm{Fe})^{39)}$ に吸収があり, サファイア結晶の品質に大きく 左右されるためである.

一方で $\mathrm{Ga}_{2} \mathrm{O}_{3}$ の最安定相は $\beta-\mathrm{Ga}_{2} \mathrm{O}_{3}$ であり, 通常の結晶 成長手法では $\beta$ 相のみが得られる。準安定相である $\alpha-\mathrm{Ga}_{2} \mathrm{O}_{3}$ の最初の報告は1925年のGoldschmidtによるもの であり ${ }^{40)}$, 続いてFosterらによって $\alpha-\mathrm{Ga}_{2} \mathrm{O}_{3}$ 結晶は常温常 圧下では熱エネルギー的に準安定相である事が見出さ れた ${ }^{41)}$. それから10年以上後で, Remeikaにより $\beta-\mathrm{Ga}_{2} \mathrm{O}_{3}$ 粉末を $44 \mathrm{kbar}$ (約44000 気圧)，1000 ${ }^{\circ} \mathrm{C}$ の条件下で加熱 および加圧することで $\alpha-\mathrm{Ga}_{2} \mathrm{O}_{3}$ の粉末結晶になる事が報 告された ${ }^{42)}$. しかしながら，それから40年近く経っても 単相の $\alpha-\mathrm{Ga}_{2} \mathrm{O}_{3}$ 結晶薄膜を合成する事は出来ず, その光 学バンドギャップ值はナノ結晶 ${ }^{43}$ 等で報告されている 程度であった。しかし2008年にミストCVD法により，c 軸配向した高い結晶性をもつ $\alpha-\mathrm{Ga}_{2} \mathrm{O}_{3}$ 薄膜の作製が行わ れ， $5.3 \mathrm{eV}$ という光学バンドギャップ值が報告されてい る ${ }^{18)}$. この報告の後, ハイドライド気相成長法 (Hydride Vapor Phase Epitaxy : HVPE法) でも単相の $\alpha-\mathrm{Ga}_{2} \mathrm{O}_{3}$ 薄膜が

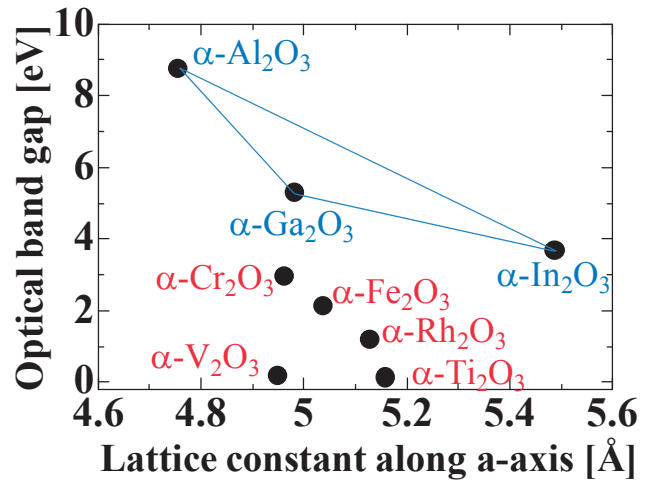

Fig. 4 A relationships between lattice length of a-axis and optical band gaps of corundum-structured oxides ${ }^{33)}$.

作製可能である事が報告され ${ }^{44)}$ ，今後その物性が明らか になる事が期待される.

$\mathrm{In}_{2} \mathrm{O}_{3}$ の最安定相はbixbyite構造であり, コランダム構 造をもつ $\alpha-\mathrm{In}_{2} \mathrm{O}_{3}$ の作製に関する報告はきわめて少ない. また, 間接遷移, 直接遷移型半導体のどちらであるか議 論されており，間接遷移と仮定すると光学バンドギャッ プ值は $3.16 \mathrm{eV}$, バンドギャップ值は $3.02 \mathrm{eV}$ となり, 直接 遷移と仮定するとそれぞれ $3.40 \mathrm{eV}, 3.26 \mathrm{eV}$ と報告されて いる ${ }^{45)}$. しかしながら，2012年にミストCVD法により c 面サファイア基板上に配向成長した $\alpha-\mathrm{In}_{2} \mathrm{O}_{3}$ 単相薄膜の 作製が初めて報告され ${ }^{31)}$, そのXRDロッキングカーブ半 值幅が $182 \operatorname{arcsec}$ と高品質のものであった. また同論文で は光学バンドギャップ值を $3.7 \mathrm{eV}$ と報告されており， $\alpha-\mathrm{In}_{2} \mathrm{O}_{3}$ のバンドギャップ值の同定は今後の議論が待た れる.

以上から, $\alpha-\mathrm{Al}_{2} \mathrm{O}_{3}{ }^{46)}, \alpha-\mathrm{Ga}_{2} \mathrm{O}_{3}{ }^{47)}, \alpha-\mathrm{In}_{2} \mathrm{O}_{3}{ }^{48)}$ の光学バ ンドギャップ值と密度, $\mathrm{a}$ 軸長, $\mathrm{c}$ 軸長, 金属のイオン半 径值(Shannonの有効イオン半径) ${ }^{49)}$ をTable 2 に示す.この ように準安定相の $\alpha-\mathrm{Ga}_{2} \mathrm{O}_{3}, \alpha-\mathrm{In}_{2} \mathrm{O}_{3}$ はミストCVD法によ って作製され，未解明であった物性が明らかにされよう としている.

$3 \cdot 3$ コランダム構造典型金属酸化物のデバイス応用

一方で, コランダム構造典型金属酸化物を用いたデバ イス開発も行われており，主に次世代のパワーデバイス 材料として注目されている. 光学バンドギャップ值5.3 $\mathrm{eV}$ 有する $\alpha-\mathrm{Ga}_{2} \mathrm{O}_{3}$ は，その大きなバンドギャップに注 目した整流デバイスへの応用がなされ, まず2013年にPt 電極を用いた横型ショットキーバリアダイオード

(Schottky barrier diode: SBD)が報告された ${ }^{50)}$. しかしなが らそのON/OFF值は $10^{4}$ 未満と小さく, 順方向電流の值も $10 \mathrm{~V}$ で $100 \mu \mathrm{A}$ 未満であった。 そこで $\alpha-\mathrm{Ga}_{2} \mathrm{O}_{3}$ 薄膜の表面

\begin{tabular}{|c|c|c|c|c|c|}
\hline Crstal & $\begin{array}{c}\text { Density } \\
{\left[\mathrm{g} / \mathrm{cm}^{3}\right]}\end{array}$ & $\begin{array}{c}\text { a-axis length } \\
{[\AA]}\end{array}$ & $\left.\begin{array}{c}\text { c-axis length } \\
{[\AA]}\end{array}\right]$ & $\begin{array}{c}\text { Ionic radii } \\
{[\mathbf{A}]}\end{array}$ & $\begin{array}{c}\text { Opt.band gap } \\
{[\mathrm{eV}]}\end{array}$ \\
\hline$\alpha-\mathrm{Al}_{2} \mathrm{O}_{3}$ & 3.9956 & 4.754 & 12.99 & 0.535 & 8.75 \\
\hline$\alpha-\mathrm{Ga}_{2} \mathrm{O}_{3}$ & 6.4666 & 4.9825 & 13.433 & 0.62 & 5.3 \\
\hline$\alpha-\mathrm{In}_{2} \mathrm{O}_{3}$ & 7.3115 & 5.487 & 14.51 & 0.8 & 3.7 \\
\hline
\end{tabular}

Table.2 Crystal parameters of corundum-structured $\alpha-\mathrm{Al}_{2} \mathrm{O}_{3}, \quad \alpha-\mathrm{Ga}_{2} \mathrm{O}_{3}, \quad \alpha-\mathrm{In}_{2} \mathrm{O}_{3}$. 
平坦性を改善し, また膜中の不純物密度を低減すること

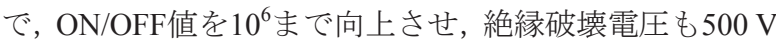
以上と高い值を示す横型SEDの作製が報告された ${ }^{51)}$. し かしながら， Snドープにより $\mathrm{n}$ 型伝導を示す $\alpha-\mathrm{Ga}_{2} \mathrm{O}_{3}$ の移 動度は当時の報告值で $2.8 \mathrm{~cm}^{2} / \mathrm{Vs}$ であり ${ }^{52)}$, また基板であ るサファイアの熱伝導率が低いため, $\alpha-\mathrm{Ga}_{2} \mathrm{O}_{3}$ の自立基 板作製による縦型SBDの開発が(株)FLOSFIAによってな された ${ }^{53), 54)}$. その結果, オン抵抗と絶縁破壊電圧の值 について, $\left(0.1 \mathrm{~m} \Omega \cdot \mathrm{cm}^{2}, 531 \mathrm{~V}\right),\left(0.4 \mathrm{~m} \Omega \cdot \mathrm{cm}^{2}, 855 \mathrm{~V}\right)$ の 值が得られ，そこから算出されたオン抵抗值は 0.1 $\mathrm{m} \Omega \cdot \mathrm{cm}^{2}$ と $\mathrm{SiC} \mathrm{SBD}$ 約7分の1の值であった ${ }^{55)}$. さらに最 近の報告として，コランダム構造をもつ $\mathrm{p}$ 型酸化物半導 体である $\alpha-\mathrm{Rh}_{2} \mathrm{O}_{3}$ と $\alpha-\mathrm{Ir}_{2} \mathrm{O}_{3}$ の作製に成功し， $\alpha-\mathrm{Ga}_{2} \mathrm{O}_{3}$ をべ 一スとするバイポーラトランジスタ実現への道筋を示 す結果となった ${ }^{56), 57)}$.

また $\alpha-\mathrm{In}_{2} \mathrm{O}_{3}$ 薄膜も, 製膜に成功した当初は電子キャリ 密度が2. $3 \times 10^{18} / \mathrm{cm}^{3}$, 移動度が $93 \mathrm{~cm}^{2} / \mathrm{Vs}^{31)}$ であり, キ ヤリア密度が高いため良好なショットキー電極の作製 が困難であり，まずはノーマリーオン型のMOSFETが作 製された。その ON/OFF值を $10^{2}$ ほどであり，電流值制御 の範囲も非常に狭かった. その原因として $\alpha-\mathrm{Fe}_{2} \mathrm{O}_{3}$ バッフ ア一層から $\alpha-\mathrm{In}_{2} \mathrm{O}_{3}$ 薄膜への $\mathrm{Fe}$ の拡散による, 不純物準位 の形成が考えられ(Fig.5), バッファー層を $\alpha-\mathrm{Fe}_{2} \mathrm{O}_{3}$ から $\alpha-\mathrm{Ga}_{2} \mathrm{O}_{3}$ に変更して作製した。 さらに酸素䨌囲気下でア ニール処理を行うことで, キャリア密度を $1.3 \times 10^{19} / \mathrm{cm}^{3}$ から $5.9 \times 10^{18} / \mathrm{cm}^{3}$ に低減し，移動度は $109 \mathrm{~cm}^{2} / \mathrm{Vs}$ から 130 $\mathrm{cm}^{2} / \mathrm{Vs}$ 向上した。 そしてこの条件で作製した $\alpha-\mathrm{In}_{2} \mathrm{O}_{3}$ 薄膜において，ON/OFF值が $10^{6}, V g<0$ においてゲー 卜電流が $1 \mathrm{nA}$ 未満の良好なMOSFET動作を確認した (Fig.6) ${ }^{29)}$.

\section{4 結 言}

酸化物と人類の最初の関り合いは，酸化物を「取り除 く」事か始まったが，磁器やガラスの発明を経て徐々に その物性が着目され，現代では必要不可欠なものとなっ ている．また半導体応用を見据えた場合に，新しい酸化 物としてコランダム構造酸化物が注目されており，まだ 未解明な部分が多い，その物性から半導体デバイス応用 までを詳述した。今後は，いよいよ「酸化物単結晶」に よるデバイスの実現が次なる目標となる事が予想され， 今後その実用化と展開が大いに期待される.

\section{参 考 文 献}

1) M. Kitada, "Elementary Metal Physics" AGNE pp.3-6 (1978) .

2) K.Kaneko, "Fabrication and physical properties of corudum-structured alloys based on gallium oxide." Doctor Thesis, Kyoto University, pp.5-6 (2013)

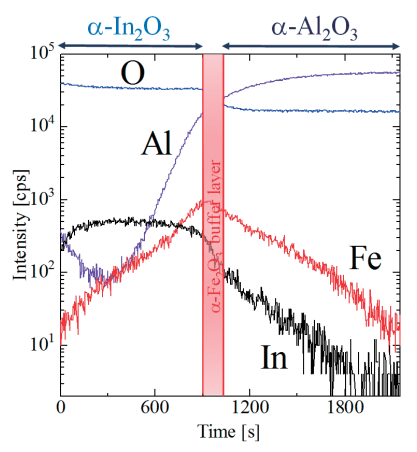

Fig.5 SIMS spectrum of an $\alpha-\operatorname{In}_{2} \mathrm{O}_{3}$ thin film, a $\alpha-\mathrm{Fe}_{2} \mathrm{O}_{3}$ buffer layer and a sapphire substrate.

(a)

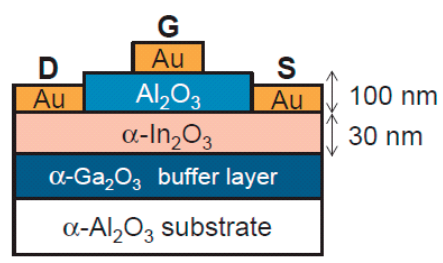

(b)

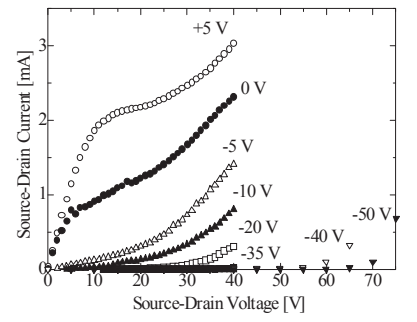

Fig. 6 (a) a cross-sectional schematic image of $\alpha-\operatorname{In}_{2} \mathrm{O}_{3}$ MOSFET and (b) its drain transfer characteristics ${ }^{29}$.

3) A. Kawabata, and T. Ohmori, "Material engineering of electrical and electronics engineering", BAIFUKAN, pp.20-21 (1987).

4) J. G. Bednorz and K. A. Müller, "Possible high Tc superconductivity in the $\mathrm{Ba}-\mathrm{La}-\mathrm{Cu}-\mathrm{O}$ system" Zeitschrift für Physik B Condensed Matter, Vol.64 Iss.2 pp.189-193 (1986).

5) S. Uchida, H. Takagi, K. Kitazawa and S. Tanaka, "High Tc Superconductivity of La-Ba-Co oxides" Japanese Journal of Applied Physics Vol.26 No. 1 pp. L 1-L 2 (1987).

6) M. K. Wu, J. R. Ashburn, C. J. Torng, P. H. Hor, R. L. Meng, L. GaO, Z. J. Huang, Y. Q. Wang and C. W. Chu, "Superconductivity at $93 \mathrm{~K}$ in a new mixed-phase Y-Ba-Cu-O compound system at ambient pressure" Physical Revew Letter Vol.58 Iss.9 pp. $908-910$ (1987).

7) L. Gao, Y. Y. Xue, F. Chen, Q. Xiong, R. L. Meng, D. Ramirez, C. W. Chu, J. H. Eggert and H. K. Mao, 
"Superconductivity up to $164 \mathrm{~K}$ in

$\mathrm{HgBa}_{2} \mathrm{Ca}_{m-1} \mathrm{Cu}_{m} \mathrm{O}_{2 m+2+\delta}(m=1,2$, and 3) under quasihydrostatic pressures", Physcal Revew B Vol.50 pp.4260-4263 (1994).

8) Y. Kamihara, T. Watanabe, M. Hirano and H. Hosono, "Iron-based layered superconductor $\mathrm{La}\left[\mathrm{O}_{1-x} \mathrm{~F}_{x}\right] \mathrm{FeAs}(x$ $=0.05-0.12$ ) with $\mathrm{Tc}=26 \mathrm{~K}$, Journal of American Chemical Society, Vol.130 pp. 3296-3297 (2008).

9) D.F. Shriver, P.W. Atkins, "Inorganic chemistry Third edition”, Tokyo Kagaku Dojin, pp. 237-239 (2001).

10) K. Adachi, "Magnetism of compounds Localised spin system" SHOKABO, pp.9-39 (2007).

11) N. Tsuda, K. Nasu, A. Fujimori, K. Siratori, "Electronic conduction in oxides" SHOKABO, pp.1-2 (2006).

12) A. Tsukazaki, A. Ohtomo, T. Kita, Y. Ohno, H. Ohno, and M. Kawasaki, "Quantum hall effect in polar oxide heterostructures", Science, Vol.315, pp.1388-1391 (2007).

13) A. Tsukazaki, S. Akasaka, K. Nakahara, Y. Ohno, H. Ohno, D. Maryenko, A. Ohtomo, and M. Kawasaki, "Observation of the fractional quantum Hall effect in an oxide”, Nature Materials, Vol.9, pp.889-893 (2010).

14) A. Tsukazaki, M. Kubota, A. Ohtomo, T. Onuma, K. Ohtani, H. Ohno, S. F. Chichibu, M. Kawasaki, "Blue light-emitting diode based on $\mathrm{ZnO}$ ”, Japanese Journal of Applied Physics, Vol.44, No.21, pp. L643-L645 (2005).

15) T. Kawaharamura, H. Nishinaka, K. Kametani, Y. Masuda, M. Tanigaki, and S. Fujita, "Fabrication and properties of $\mathrm{ZnO}$ thin films prepared by fine channel mist method", Journal of the Society of Materials Science, Japan, Vol.55, No.2, pp.153-158 (2006).

16) H. Nishinaka, T. Kawaharamura, and S. Fujita, "Low-temperature growth of $\mathrm{ZnO}$ thin films by linear source utrasonic spray chemical vapor deposition", Japanese Journal of Applied Physics, Vol.46, No.10A, pp.6811-6813 (2007).

17) K. Kaneko, H. Kawanowa, H. Ito and S. Fujita, "Evaluation of Misfit Relaxation in $\alpha-\mathrm{Ga}_{2} \mathrm{O}_{3}$ Epitaxial Growth on $\alpha-\mathrm{Al}_{2} \mathrm{O}_{3}$ Substrate", Japanese Journal of Applied Physics, Vol.51, No.2R, pp.020201(1-3) (2012).

18) D. Shinohara and S. Fujita, "Hetero-epitaxy of corundum-structured $\alpha-\mathrm{Ga}_{2} \mathrm{O}_{3}$ thin films on $\alpha-\mathrm{Al}_{2} \mathrm{O}_{3}$ substrates by ultrasonic mist chemical vapor deposition", Japanese Journal of Applied Physics, Vol.47, No.9, pp.7311-7313 (2008).

19) K. Kaneko, H. Ito, S.-D. Lee, and Shizuo Fujita, "Oriented growth of beta gallium oxide thin films on yttrium-stabilized zirconia substrates", Physica Status Solidi (c), Vol.10, No.11, pp.1596-1599, (2013).

20) T. Oshima, T. Nakazono, A. Mukai and A. Ohtomo, "Epitaxial growth of $\gamma-\mathrm{Ga}_{2} \mathrm{O}_{3}$ films by mist chemical vapor deposition" Journal of Crystal Growth Vol.359, pp.60-63 (2012).

21) S. Yubuchi, Y. Ito, T. Matsuyama, A. Hayashi and M. Tatsumisago, "5V Class $\mathrm{LiNi}_{0.5} \mathrm{Mn}_{1.5} \mathrm{O}_{4}$ Positive Electrode Coated with $\mathrm{Li}_{3} \mathrm{PO}_{4}$ Thin Film for All-Solid-State Batteries Using Sulfide Solid Electrolyte", Solid State Ionics, Vol.285, pp.79-82 (2016).

22) T. Igawa, K. Kaneko, and S. Fujita, "Fabrication of Lithium-based oxide thin films by ultrasonic-assisted mist CVD technique”, Vol.60, No.11, pp.994-997 (2011)

23) K. Tadanaga, A. Yamaguchi, A. Sakuda, A. Hayashi, M. Tatsumisago, A. Duran , and M. Aparacio, "Preparation of $\mathrm{LiMn}_{2} \mathrm{O}_{4}$ cathode thin films for thin film lithium secondary batteries by a mist CVD process" Materials Research Bulletin Vol.53, pp. 196-198 (2014)

24) T. Takagi, H. Tanaka, Shiz. Fujita, and Shig. Fujita, "Molecular Beam Epitaxy of High Magnesium Content

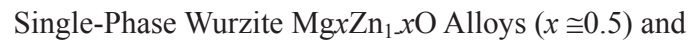
Their Application to Solar-Blind Region Photodetectors", Japanese Journal of Applied Physics, Vol.42, No.4B, pp. L401-L403 (2005).

25) T. Uchida, T. Kawaharamura, K. Shibayama, T. Hiramatsu, H. Orita, and S. Fujita, "Mist chemical vapor deposition of aluminum oxide thin films for rear surface passivation of crystalline silicon solar cells", Applied Physics Express, Vol.7, No.2, 021303(1-4), (2014).

26) T. Oshima, T. Okuno, and S. Fujita, " $\mathrm{Ga}_{2} \mathrm{O}_{3}$ thin film growth on c-plane sapphire substrates by molecular beam epitaxy for deep-ultraviolet photodetectors", Japanese Journal of Applied Physics, Vol.46, No.11, pp.7217-7220 (2007).

27) M. Higashiwaki, K. Sasaki, A. Kuramata, T. Masui, and S. Yamakoshi, "Gallium oxide $\left(\mathrm{Ga}_{2} \mathrm{O}_{3}\right)$ metal-semiconductor field-effect transistors on 
single-crystal $\beta-\mathrm{Ga}_{2} \mathrm{O}_{3}(010)$ substrates", Applied Physics Letters, Vol.100, No.1, 013504(1-3) (2012).

28) M. Oda, R. Tokuda, H. Kambara, T. Tanikawa, T. Sasaki, and T. Hitora, "Schottky barrier diodes of corundum-structured gallium oxide showing on-resistance of $0.1 \mathrm{~m} \Omega \mathrm{cm}^{-2}$ grown by MIST

EPITAXY®”, Applied Physics Express, Vol.9, No.2, 021101(1-3) (2016).

29) K. Kaneko, Y. Ito, T. Uchida and S. Fujita, "Growth and metal-oxide-semiconductor field-effect transistors of corundum-structured alpha indium oxide semiconductors" Applied Physics Express, Vol.8, No.9, 095503(1-4) (2015).

30) N. Bârsan, R. Ionescu, " $\mathrm{SnO}_{2}$-based gas sensors as chromatographic detectors", Sensors and Actuators B, Vol.19, Iss.1-3, pp. 470-473 (1994).

31) N. Suzuki, K. Kaneko, and S. Fujita, "Growth of corundum-structured $\operatorname{In}_{2} \mathrm{O}_{3}$ thin films on sapphire substrates with $\mathrm{Fe}_{2} \mathrm{O}_{3}$ buffer layers", Journal of Crystal Growth, Vol.364, Iss.2, pp.30-33 (2013).

32) H. Ito, K. Kaneko, and S. Fujita, "Growth and band gap control of corundum-structured $\alpha-(\mathrm{AlGa})_{2} \mathrm{O}_{3}$ thin films on sapphire by spray-assisted mist chemical vapor deposition” Japanese Journal of Applied Physics, Vol.51, No.10, 100207(1-3),(2012).

33) K. Kaneko, I. Kakeya, S. Komori, and S. Fujita, "Band gap and function engineering for novel functional alloy semiconductors: Bloomed as magnetic properties at room temperature with $\alpha-(\mathrm{GaFe})_{2} \mathrm{O}_{3}$ ", Journal of Applied Physics, Vol.113, Iss.23, pp. 233901(1-6) (2013).

34) F. S. Galasso, "Structure and properties of inorganic solids" AGNE, pp.267-270 (2010)

35) R. W. G. Wyckoff, “Crystal Structure” Vol.2 Wiley, New York (1964)

36) E. T. Arakawa and M. W. Williams, "Optical properties of aluminum oxide in the vacuum ultraviolet", Journal of Physics and Chemistry of Solids, Vol.29, Iss.5, pp. 735-744 (1968).

37) M. E. Innocenzi, R. T. Swimm, M. Bass, R. H. French, A. B. Villaverde, and M. R. Kokta, "Room temperature optical absorption in undoped $\alpha-\mathrm{Al}_{2} \mathrm{O}_{3}$ ", Journal of Applied Physics, Vol.67, pp. 7542-7546 (1990).
38) E. Loh, "Ultraviolet Absorption and Excitation Spectrum of Ruby and Sapphire", Journal of Chemical Physics Vol.44, No. 5 pp.1940-1945 (1966).

39) H. H. Tippins, "Charge-Transfer Spectra of Transition-Metal Ions in Corundum", Physical Review B, Vol.1, No.1 pp.126-135 (1970).

40) V. M. Goldschmidt, T. Barth, and G. Lunde, "Geochemical Distribution Laws of the Elements: V, Isomorphy and Polymorphy of the Sesquioxides" Skrifter Notske Videnskaps-Akad., Oslo, I. Material Naturv. Klasse Vol. 7 pp.59 (1925)

41) L. M. Foster and H. C. Stumpf, "Analogies in the gallia and alumina systems. The preparation and properties of some low-alkali gallates" Journal of The Amrican Chemical Society, Vol.73, pp.1590-1595 (1951).

42) J. P. Remeika and M. Marezio, "Growth of $\alpha-\mathrm{Ga}_{2} \mathrm{O}_{3}$ single crystals at 44 Kbars" Applied Physics Letter Vol.8, No.4, pp.87-88 (1966)

43) G. Sinha, K. Adhikary, and S. Chaudhuri, "Sol-gel derived phase pure $\alpha-\mathrm{Ga}_{2} \mathrm{O}_{3}$ nano crystalline thin film and its optical properties", Journal of Crystal Growth Vol.276, Iss.1-2, pp.204-207 (2005).

44) Y. Oshima, E. G. Víllora, and K. Shimamura, "Halide vapor phase epitaxy of twin-free $\alpha-\mathrm{Ga}_{2} \mathrm{O}_{3}$ on sapphire (0001) substrates", Applied Physics Express Vol.8, No.5, pp. 055501(1-4) (2015)

45) P. D. C. King, T. D. Veal, F. Fuchs, Ch. Y. Wang, D. J. Payne,A. Bourlange,H. Zhang,G. R. Bell,V. Cimalla,O. Ambacher,R. G. Egdell,F. Bechstedt,and C. F. McConville, "Band gap, electronic structure, and surface electron accumulation of cubic and rhombohedral $\mathrm{In}_{2} \mathrm{O}_{3}$ ”, Physical Review B, Vol.79, pp.205211(1-10) (2009).

46) N. Ishizawa, T. Miyata, I. Minato, F. Marumo and S. Iwai, "A structure investigation of $\alpha-\mathrm{Al}_{2} \mathrm{O}_{3}$ at $2170 \mathrm{~K}$ ", Acta Crystallographica Section B Vol.36 pp.228-230 (1980).

47) M. Marezio and J. P. Remeika, "Bond lengths in the $\alpha-\mathrm{Ga}_{2} \mathrm{O}_{3}$ structure and the high-pressure phase of $\mathrm{Ga}_{2-\mathrm{x}} \mathrm{Fe}_{\mathrm{x}} \mathrm{O}_{3}$ ", Journal of Chemical Physics Vol.46, pp.1862-1865 (1967).

48) C. T. Prewitt, R. D. Shannon, D. B. Rogers, A. W. Sleight, " $\mathrm{C}$ rare earth oxide-corundum transition and crystal chemistry of oxides having the corundum structure", Inorganic Chemistry, Vol.8 pp.1985-1993 (1969). 
49) R.D. Shannon, "Revised effective ionic radii and systematic studies of interatomic distances in halides and chalcogenides", Acta Crystallographica, vol.32, iss.5, pp.751-767 (1976)

50) M. Oda and T. Hitora, "Growth of High Quality $\alpha$-Ga2O3 Thin Films on 4-Inch Sapphire Wafer" Materials Reserch Conference Fall Meting 2013.

51) M.Oda, A. Takatsuka, T. Hitora, J. Kikawa, K. Kaneko, and S. Fujita, " $\alpha-\mathrm{Ga}_{2} \mathrm{O}_{3}$ Schottky barrier diodes fabricated by Mist Epitaxy technique" 46th International Conference on Solid State Device and Materials N-1-5

52) K. Akaiwa and S. Fujita, "Electrical conductive corundum-structured $\alpha-\mathrm{Ga} 2 \mathrm{O} 3$ thin films on sapphire with tin-doping grown by spray-assisted mist chemical vapor deposition" Japanese Journal of Applied Physics, Vol 51, No.7R 070203(1-3) (2012).

53) IEEE SPECTRUM "Gallium Oxide: Power Electronics' Cool New Flavor" Posted 30 Mar 2016 | 15:00 GMT http://spectrum.ieee.org/semiconductors/materials/galliu m-oxide-power-electronics-cool-new-flavor

54) R. Stevenson, "Getting the most out of gallium oxide" Compound Semiconductor Vol. 22 Iss. 5 pp.3 (2016) from editorial view.

55) M. Oda, R. Tokuda, H. Kambara, T. Tanikawa, T. Sasaki, and T. Hitora, "Schottky barrier diodes of corundum-structured gallium oxide showing on-resistance of $0.1 \mathrm{~m} \Omega \mathrm{cm}^{-2}$ grown by MIST EPITAXY ${ }^{\circledR}$,, Applied Physics Express, Vol.9, No.2, 021101(1-3) (2016).

56) K. Kaneko, T. Hitora, S. Fujita, "Study on novel semiconductors with p-type conductivity", 77th Fall Meeting 2016, Japan Society of Applied Physics and Related Societies, 15a-A22-11.

57) "Making of a p-type semiconductor for realizing of pn junction with $\mathrm{Ga}_{2} \mathrm{O}_{3}$ " Nikkei Technology online, Sep. 28, 2016. http://techon.nikkeibp.co.jp/atcl/news/16/092804 278/?ST=powerele 